\title{
ANALISIS PENGARUH RELATIONSHIP MARKETING TERHADAP LOYALITAS PELANGGAN PADA PT. PANGKALAN BARU INDAH PEKANBARU
}

\author{
ANALYSIS INFLUENCES OF RELATIONSHIP MARKETING \\ ON CUSTOMERS' LOYALTY \\ IN PT. PANGKALAN BARU INDAH PEKANBARU
}

\author{
Yusnita Octafilia ${ }^{1}$, Mira Oktavia ${ }^{2}$ \\ Sekolah Tinggi Ilmu Ekonomi Pelita Indonesia ${ }^{1,2}$ \\ octafila@yahoo.com ${ }^{1}$, mira_oktavia78@yahoo.com ${ }^{2}$
}

\begin{abstract}
Riau is one of the provinces with the largest number of Palm Oil Mill in Indonesia. The large amount of existing Palm Oil Mill and the less amount of customers makes Palm Oil Mill must be able to maintain their business relationship in order to stabilize their selling. The existence of intense competition and the necessity to maintain their business relationship are a phenomenon of this research so the purpose of this study is to analyze the influence of Relationship Marketing Inputs to customer loyalty at PT. Pangkalan Baru Indah Pekanbaru. The research is used questionnaires method on 65 customers of PT. Pangkalan Baru Indah Pekanbaru. Data analysis method on this research is used quantitative analysis which analyzes through statistical calculation using software program SPSS version 19.0. The result of this research shows understanding customer expectation, building service partnership dan total quality management have positive and significant effect to customer loyalty in PT. Pangkalan Baru Indah while empowering employees has no significant effect to customer loyalty of PT. Pangkalan Baru Indah Pekanbaru.
\end{abstract}

Keywords : Relationship Marketing, Understanding Customer Expectation, Building Service Partnership, Total Quality Management, Empowering Employees and Customer Loyalty

\footnotetext{
ABSTRAK

Provinsi Riau merupakan salah satu provinsi dengan jumlah Pabrik Kelapa Sawit terbanyak di Indonesia. Banyaknya PKS yang ada dan jumlah pelanggan yang tidak terlalu banyak membuat setiap PKS harus bisa mempertahankan relasinya agar penjualan tidak menurun. Adanya persaingan yang ketat dan keharusan mempertahankan relasi merupakan fenomena yang melatarbelakangi penelitian ini sehingga tujuan dari penelitian ini adalah untuk menganalisa pengaruh Relationship Marketing Inputs terhadap loyalitas pelanggan pada PT. Pangkalan Baru Indah Pekanbaru. Penelitian ini dilakukan dengan metode kuesioner terhadap 65 orang pelanggan PT. Pangkalan Baru Indah Pekanbaru. Metode analisis data yang digunakan adalah analisis kuantitatif yaitu menganalisis melalui perhitungan statistik dengan bantuan program SPSS versi 19.0. Hasil analisis data menunjukan bahwa understanding customer expectation, building service partnership dan total quality management berpengaruh positif dan signifikan terhadap loyalitas pelanggan PT. Pangkalan Baru Indah sedangkan variabel empowering employees tidak berpengaruh dan tidak signifikan terhadap loyalitas pelanggan PT. Pangkalan Baru Indah.

Kata Kunci : Relationship Marketing, Understanding Customer Expectation, Building Service Partnership, Total Quality Management, Empowering Employees dan Loyalitas Pelanggan.
} 


\section{PENDAHULUAN}

Pembangunan sektor industri hampir selalu menjadi prioritas utama dalam pembangunan negara negara berkembang. Hal ini dikarenakan sektor industri dianggap dapat mendorong pertumbuhan sektor lainnya seperti sektor jasa dan sektor perkebunan. Salah satu industri yang sedang berkembang di Indonesia khususnya pada Provinsi Riau adalah industri kelapa sawit. Peningkatan permintaan terhadap produk - produk yang dihasilkan dari kelapa sawit seperti crude palm oil atau minyak kelapa sawit menjadi salah satu alasan berkembangnya sektor industri kelapa sawit. Kelapa sawit merupakan salah satu komoditi yang menjadi andalan di sebagian besar wilayah Indonesia karena kelapa sawit mempunyai potensi sebagai andalan ekspor dan juga diharapkan menjadi komoditi yang dapat meningkatkan pendapatan dari petani. Pada dasarnya kelapa sawit dipanen dalam bentuk Tandan Buah Segar (TBS) yang akan diolah menjadi beberapa produk turunan yang mempunyai harga jual.

Provinsi Riau merupakan salah satu provinsi dengan jumlah perkebunan sawit terbanyak di Indonesia. Hal inilah yang mendasari banyak nya pabrik kelapa sawit yang berdiri di Provinsi Riau. Sebanyak 146 Pabrik Kelapa Sawit (PKS) tersebar di berbagai kabupaten atau kota di Provinsi Riau (Dirjen Perkebunan, 2016). Produk yang dihasilkan dari industri kelapa sawit berbeda dengan produk yang dihasilkan dari industri lain seperti makanan dan minuman, dimana produk dari industri kelapa sawit tidak dapat dibeli oleh semua kalangan. Pembeli atau pun pelanggan dari PKS biasanya merupakan perusahaan - perusahaan yang mengeskpor minyak kelapa sawit keluar negeri ataupun perusahaan yang membuat minyak makan dari minyak kelapa sawit. Sehingga jumlah pelanggan atau pun pembeli dari industri ini tidaklah banyak. Melihat dari banyaknya PKS yang ada dan jumlah pelanggan yang tidak terlalu banyak, maka setiap PKS harus bisa menyusun strategi untuk memasarkan produknya dan juga mempertahankan pelanggan yang ada.

PT. Pangkalan Baru Indah merupakan salah satu PKS yang telah berdiri sejak tahun 2011 di Provinsi Riau. Produk - produk yang dihasilkan PT. Pangkalan Baru Indah berupa minyak kelapa sawit (Crude Palm Oil), inti kelapa sawit (Palm Kernel), cangkang dan beberapa produk turunan dari kelapa sawit. Untuk mempertahankan eksistensinya dan juga untuk menjaga loyalitas pelanggan, PT. Pangkalan Baru Indah berusaha untuk menerapkan strategi pemasaran yang dapat menjaga hubungan baiknya denganpelanggan.

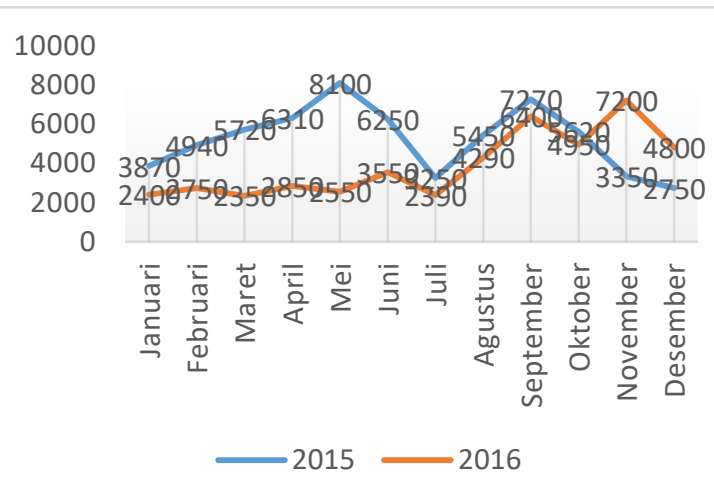

Sumber: Data Olahan

Gambar 1. Data Penjualan PT. Pangkalan Baru Indah Tahun 2015 dan 2016 
Dari data diatas, diketahui bahwa terjadi penurunan total volume penjualan dari tahun $2015 \mathrm{ke}$ tahun 2016 yaitu sebesar 16.400.000 Kg. Pada tahun 2016, volume penjualan selalu mengalami penurunan jika dibandingkan dengan tahun 2015. Volume penjualan pada bulan Januari hingga Oktober tahun 2015 selalu lebih tinggi daripada tahun 2016, akan tetapi hal ini justru berbanding terbalik pada 2 bulan berikutnya. Dimana pada bulan November dan Desember 2016, volume penjualan justru mengalami peningkatan jika dibandingkan dengan tahun sebelumnya.

PT. Pangkalan Baru Indah berupaya untuk tetap menjaga loyalitas pelanggan agar penurunan penjualan dapat diatasi, yaitu dengan mengubah cara pandang dari yang berorientasi pada produk ke pandangan yang berorientasi pada pelanggan. Loyalitas pelanggan merupakan kelekatan pelanggan pada suatu merek, toko, pabrikan, pemberi jasa, atau identitas lain berdasarkan sikap yang menguntungkan dan tanggapan yang baik, seperti pembelian ulang. Loyalitas pelanggan juga bisa diartikan pelanggan yang tidak hanya membeli ulang suatu barang dan jasa, tetapi juga mempunyai komitmen dan sikap yang positif terhadap perusahaan jasa, misalnya dengan merekomendasikan orang lain untuk membeli.

Salah satu strategi yang digunakan PT. Pangkalan Baru Indah untuk menjaga loyalitas pelanggan adalah dengan Relationship Marketing. Relationship Marketing memaparkan bahwa loyalitas pelanggan bisa dibangun dengan menjadikan pelanggan sebagai inti dari aktivitas pemasaran.
Relationship Marketing merupakan suatu pendekatan jangka panjang, dimana hal ini berbeda dengan pendekatan pemasaran transaksional yang merupakan pendekatan jangka pendek. Tujuan utama dalam pemasaran transaksional adalah untuk mendapatkan pelanggan semata, sedangkan tujuan utama dari Relationship Marketing adalah mendapat dan mempertahankan pelanggan. Sehingga dengan adanya strategi Relationship Marketing berupaya memperpanjang umur waktu hidup pelanggan sebagai individu yang bertransaksi dan juga menjaga loyalitas pelanggan. Tujuan dari penelitian ini adalah untuk menganalisa pengaruh Relationship Marketing Inputs terhadap loyalitas pelanggan pada PT. Pangkalan Baru Indah Pekanbaru.

Dalam perusahaan, upaya upaya dalam Relationship Marketing Inputs bertujuan untuk menambah kedekatan dengan pelanggan dan tujuan utama dari usaha tersebut adalah agar pelangga tetap loyal. Secara lebih spesifik implementasi Relationship Marketing bertujuan untuk memperdayakan kekuatan keinginan pelanggan yaitu dengan memahami harapan pelanggan (Understanding Customer Expectation) yang dapat dilakukan dengan menghasilkan produk yang sesuai dengan keinginan pelanggan, harga yang dapat dijangkau oleh pelanggan, menyediakan fasilitas sesuai dengan harapan pelanggan dan merespon komplain dari pelanggan. Relationship Marketing Inputs yang kedua adalah dengan membangun kerjasama dengan pelanggan (Building Service Partnership). Hal ini dapat dilakukan dengan mengajak pelanggan untuk ikut serta dalam program - program 
yang dilaksanakan oleh perusahaan. Menganggap pelanggan sebagai partner, memberikan layanan layanan tambahan berupa pelayanan yang cepat, selalu menjaga hubungan baik dan kerja sama dengan pelanggan. Relationship Marketing juga dapat diupayakan dengan menerapkan Total Quality Management agar produk yang dihasilkan selalu berkualitas dan sesuai dengan harapan pelanggan. Pada PT. Pangkalan Baru Indah, penerapan Total Quality Management diupayakan dengan memproduksi produk sesuai dengan standar yang telah diberikan pelanggan. Apabila produk yang dihasilkan bermutu dan sesuai dengan tuntutan yang diberikan maka pelanggan akan menjadi loyal terhadap perusahaan tersebut. Upaya terakhir yang dilakukan perusahaan dalam menerapkan Relationship Marketing adalah dengan melakukan pemberdayaan karyawan (Empowering Employees), antara lain dengan cara mendekati pelanggan untuk mengetahui apa yang dibutuhkan, karyawan berusaha sebaik mungkin dalam membantu pelanggan mengatasi masalah yang diatasi serta cepat tanggap dalam memberikan pelayanan.

Berdasarkan beberapa penelitian terdahulu yang membahas tentang pengaruh Relationship Marketing terhadap loyalitas pelanggan menunjukkan perbedaan hasil penelitian. Menurut penelitian yang dilakukan oleh Tangkilisan (2013), seluruh variabel dalam Relationship Marketing Inputs memiliki pengaruh signifikan dan positif terhadap loyalitas pelanggan. Akan tetapi, penelitian yang dilakukan oleh Rahmawati (2013) menunjukkan bahwa variabel yang memiliki pengaruh signifikan dan positif terhadap loyalitas pelanggan adalah Building Service Partnership dan Total Quality Management. Sedangkan variabel Understanding Customer Expectation dan Empowering Employees tidak berpengaruh signifikan dan positif terhadap loyalitas pelanggan.

Tujuan dari penelitian ini adalah untuk menganalisa pengaruh Relationship Marketing Inputs yang terdiri dari understanding customer expectation, building service partnership, total quality management dan empowering employees terhadap loyalitas pelanggan pada PT. Pangkalan Baru Indah Pekanbaru.

Konsep pemasaran holistic didasarkan pada pengembangan, perancangan, dan implementasi program pemasaran, proses pemasaran, dan kegiatan - kegiatan pemasaran yang mengakui keluasan dan interdependensi mereka. Pemasaran holistic mengakui bahwa "segala sesuatu bisa terjadi" pada pemasaran dan bahwa pemasaran perspektif yang luas dan terpadu sering dibutuhkan. Relationship Marketing diartikan sebagai proses dimana suatu perusahaan membangun hubungan jangka panjang dengan pelanggan dan calon pelanggan, bekerjasama untuk mencapai satu tujuan yang ditentukan (Anwar, 2016). Tujuan tersebut dipenuhi dengan memahami kebutuhan konsumen, memperlakukan konsumen sebagai mitra, menjamin bahwa para pegawai memenuhi kepuasan konsumen dan memberikan kualitas yang baik kepada konsumen

\section{Understanding Customer}

Expectation merupakan kegiatan yang melibatkan kemampuan 
perusahaan untuk melakuan identifikasi apa yang menjadi keinginan konsumen dan memasarkan barang dan jasa di atas tingkat yang mereka harapkan. Tidak mudah untuk mengidentifikasi apa yang diharapkan oleh seorang pelanggan, karena masing - masing pelanggan tentu mempunyai harapan dan keingginan yang berbeda - beda. Keinginan pelanggan juga terus mengalami perubahan seiring dengan perkembangan zaman dan trend. Untuk memenuhi keinginan pelanggan yang semakin kompleks itu, sebuah perusahaan harus bisa mengumpulkan informasi sebanyakbanyaknya tentang pelanggan dan menggunakanya pada saat yang tepat. Dengan demikian, seorang pelanggan merasa membeli sesuatu produk atau jasa yang sesuai dengan apa yang mereka harapkan (Wibowo S, 2006). Terdapat beberapa indikator dalam understanding customer expectation yaitu harga sesuai harapan, pelayanan yang memuaskan dan produk dan fasilitas yang sesuai harapan.

Building service partnership merupakan salah satu bentuk kemitraan, yaitu kerjasama yang dilakukan oleh perusahaan dengan pelanggan dalam menambahkan pelayanan yang diinginkan pelanggan atas suatu produk perusahaan. Pengalaman kemitraan ada ketika suatu perusahaan bekerja sama secara erat dengan pelanggan dan menambahkan pelayanan yang diinginkan oleh pelanggan atas suatu produk perusahaan. Dalam building service partnership kedua belah pihak, baik perusahaan maupun pelanggan, mengharapkan suatu keuntungan. Pada pihak pelanggan keuntungan bisa dalam bentuk kepuasaan pada pelayanan yang diberikan perusahaan (Saputri, dkk., 2013). Menurut Evans dan Laskin, beberapa indikator dalam building service partnership berdasarkan pada kejujuran dan keterbukaan, kolaboratif antar pihak dan komunikasi yang baik. (Anwar,2016) Total Quality Management yaitu kualitas merupakan suatu kondisi dinamis yang berhubungan dengan produk, jasa, manusia, proses, dan lingkungan yang memenuhi atau melebihi harapan. Seperti halnya dengan kualitas, definisi Total Quality Management juga ada bermacam - macam. Total Quality Management diartikan sebagai perpaduan semua fungsi dari perusahaan ke dalam falsafah holistic yang dibangun berdasarkan konsep kualitas, tim, produktivitas, dan pengertian serta kualitas pelanggan. Menurut Wibowo S (2006), beberapa indikator dalam Total Quality Management mencakup produk sesuai standar, produk yang berkualitas dan erbaikan kualitas produk dan fasilitas secara berkesinambungan

Pemberdayaan karyawan adalah memampukan dan memberi kesempatan kepada karyawan untuk merencanakan,

mengimplementasikan rencana, dan mengendalikan implementasi rencana pekerjaan yang menjadi tanggung jawabnya. Tujuan dari pemberdayaan karyawan yaitu untuk memunculkan potensi dan modalitas yang ada dalam diri karyawan dan memaksimalkannya sehingga karyawan menjadi mandiri dan meningkat kinerjanya, yang pada akhirnya memberikan nilai manfaat bagi karyawan dan organisasi (Anwar, 2016). Pemberdayaan karyawan biasanya dimaksudkan untuk memberikan kebebasan kepada 
karyawan untuk mempraktekan kreativitas mereka dalam menyelesaikan masalah konsumen, dengan memberikan otoritas lebih kepada pegawai berarti mengurangi birokrasi internal. Disamping itu pegawai yang diperbedayakan dapat mengubah hubungan yang singkat dengan konsumen menjadi hubungan jangka panjang. Menurut Evan dan Laskin, beberapa hal yang menjadi indikator dalam empowering employees adalah tanggung jawab karyawan, kemampuan karyawan dalam menanggapi dan menyelesaikan masalah dan kemampuan karyawan mengambil keputusan (Borneo K, 2011).

Tujuan utama dari Relationship Marketing adalah meningkatkan kepuasan konsumen agar menjadi pelanggan yang setia kepada perusahaan, Customer satisfaction merupakan evaluasi purna beli dimana alternatif yang dipilih sekurang-kurangnya memberikan hasil (outcomes) sama atau melampui harapan pelanggan, sedangkan ketidakpuasan timbul apabila hasil yang diperoleh tidak memenuhi harapan pelanggan (Anwar, 2016).

Kepuasan adalah tingkat perasaan seseorang setelah membandingkan kinerja atau hasil yang dirasakan dibandingkan dengan harapan sebelum membeli atau mengkonsumsi suatu barang atau jasa Kepuasan konsumen dapat tercapai apabila kebutuhan, keinginan dan harapan konsumen terpenuhi. Dengan mengetahui ada yang diinginkan oleh konsumen, akan memudahkan perusahaan dalam mengkomunikasikan produknya kepada target konsumenya (Kotler $\mathrm{P}, 2009)$.
Loyalitas didefinisikan sebagai suatu sikap yang ditunjukan oleh konsumen terhadap penyediaan produk atau jasa. Seorang konsumen akan menunjukan sikap loyalnya jika suatu perusahaan mampu memberikan kepuasan kepada konsumenya. Bagi organisasi terdapat empat manfaat utama yang berkaitan dengan loyalitas konsumen. Pertama, loyalitas meningkatkan pembelian konsumen. Kedua, Loyalitas konsumen menurunkan biaya yang ditanggung perusahaan untuk melayani konsumen. Ketiga, loyalitas konsumen meningkatkan komunikasi yang positif dari mulut ke mulut. Manfaat utama dari loyalitas konsumen adalah retensi karyawan. Karyawan pada bisnis jasa sering dipengaruhi oleh interaksi harian mereka dengan konsumen-konsumen perusahaan, karena orang cenderung lebih suka bekerja dengan organisasi-organisasi yang konsumennya loyal dan puas (Anwar, 2016)

Loyalitas didefinisikan sebagai suatu sikap yang ditunjukan oleh konsumen terhadap penyediaan produk atau jasa. Seorang konsumen akan menunjukan sikap loyalnya jika suatu perusahaan mampu memberikan kepuasan kepada konsumenya. Menurut Kotler dan Armstong (2006), loyalitas berasal dari pemenuhan harapan atau harapan konsumen, sedangkan ekspektasi sendiri berasal dari pengalaman pembelian terdahulu oleh konsumen, opini dari teman dan kerabat, janji atau informasi dari pemasar atau pesaing.

Hasil positif dari Relationship Marketing adalah mendorong perusahaan untuk memperbaiki kualitas produk atau jasa. Kualitas 
sendiri memiliki banyak kriteria yang berubah secara terus-menerus. Kualitas sering dianggap sebagai ukuran relatif kebaikan suatu produk atau jasa yang terdiri dari kualitas desain dan kualitas kesesuaian. Kualitas desain merupakan fungsi spesifikasi produk, sedangkan kualitas kesesuaian adalah ukuran seberapa jauh suatu produk memenuhi persyaratan atau spesifikasi kualitas yang ditetapkan (Anwar,2016)

Untuk berhasil proses

Relationship Marketing harus mampu menghasilkan laba jangka panjang yang lebih tinggi. Relationship Marketing inputs mungkin membutuhkan pengeluaran yang cukup besar. Tetapi, outcomes dari proses Relationship Marketing akan menghasil kinerja penjualan yang lebih baik, efisiensi biaya produksi dan pemasaran jadi akan berdampak positif pada kemampuan perusahaan menghasilkan laba (Anwar, 2016).

Relationship Marketing akan meningkatkan kepuasan konsumen, mendapatkan loyalitas konsumen yang lebih besar dan memperbaiki kualitas produk dan jasa. Apabila kondisi ini tercapai maka akan mempengaruhi kemampuan perusahaan dalam menghasilkan laba perusahaan secara positif

Anwar (2016) melakukan penelitian mengenai Kajian Implementasi Relationship Marketing Terhadap Customer Loyalty (Loyalitas Mahasiswa) (kasus pada Fakultas Ekonomi Universitas Muhammadiyah Jember). Hasil penelitian ini menunjukkan bahwa Variabel Understanding Customer Expectation, Building Service Partnership, Total Quality
Management, dan Empowering Employees berpengaruh signifikan dan positif terhadap Customer Loyalty.

Kumbokarno

melakukan penelitian mengenai Pengaruh Implemetnasi Relationship Marketing Terhadap Loyalitas Konsumen pada Produk Oli Pelumas PT. Pertamina (Persero) Enduro 4T. Hasil penelitian ini menunjukkan bahwa Variabel Understanding Customer Expectation, Building Service Partnership, Total Quality Management, dan Empowering Employees berpengaruh signifikan dan positif terhadap Customer Loyalty

Tangkilisan

melakukan penelitian mengenai Relationship Marketing Pengaruhnya Terhadap Customer Loyalty pada PT. Bank Perkreditan Rakyat Prisma Dana Manado. Hasil penelitian ini menunjukkan bahwa Variabel Understanding Customer Expectation, Building Service Partnership dan Total Quality Management berpengaruh signifikan dan positif terhadap customer loyalty. Sedangkan variabel Empowering Employees berpengaruh positif namun tidak berpengaruh signifikan Customer Loyalty

Saputri, Yaningwati dan Fanani (2013) melakukan penelitian mengenai Pengaruh Implemetnasi Relationship Marketing Terhadap Loyalitas Pelanggan (Survei pada Nasabah PT. "XXX" Cabang Malang). Hasil penelitian ini menunjukkan bahwa Variabel Understanding Customer Expectation dan Building Service Partnership berpengaruh signifikan dan positif terhadap loyalitas pelanggan. 
Rahmawati

(2013)

melakukan penelitian mengenai Pengaruh Relationship Marketing Terhadap Loyalitas Nasabah pada PT. Bank Negara Indonesia (Persero) Tbk. Cabang Malang. Hasil penelitian ini menunjukkan bahwa Variabel Building Service Partnership dan Total Quality Management berpengaruh signifikan dan positif terhadap customer loyalty. Sedangkan variabel Understanding Customer Expectation dan Empowering Employees tidak berpengaruh positif dan signifikan Customer Loyalty. Junistyaningrum dan Sugiarto (2016) melakukan penelitian mengenai Pengaruh Impelmentasi Relationship Marketing Terhadap Customer Loyalty dengan Customer Satisfaction Sebagai Variabel Intervening (Studi Pada PT. Bank Rakyat Indonesia (Persero) Tbk. Cabang Pandanaran). Hasil penelitian ini menunjukkan bahwa Variabel Building Service Partnership dan Total Quality Management berpengaruh positif dan signifikan terhadap Customer Satisfaction. Building Service Partnership dan Total Quality Management berpengaruh positif dan signifikan terhadap Customer Loyalty. Customer Satisfaction berpengaruh positif dan signifikan terhadap Customer Loyalty.

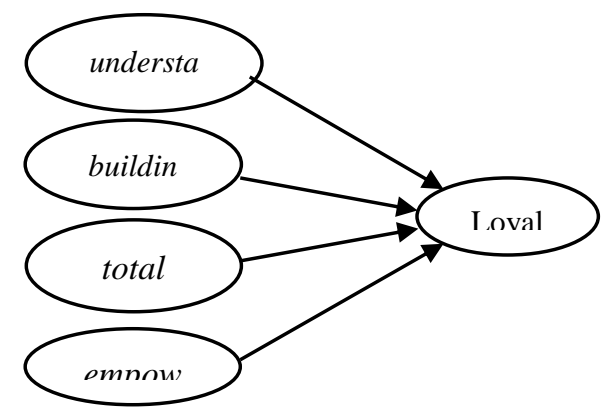

Gambar 2. Kerangka Pemikiran
Understanding Customer Expectation merupakan cara suatu perusahaan untuk dapat mengerti apa yang diinginkan oleh konsumen sehingga perusahaan dapat menghasilkan produk yang dapat melebihi harapan konsumen. Jadi semakin mengertinya perusahaan mengenai apa yang diinginkan oleh konsumen maka konsumen akan semakin loyal terhadap produk yang dijual. Karena menurut penelitian yang dilakukan oleh Anwar (2016) variabel Understanding Customer Expectation berpengaruh secara signifikan terhadap loyalitas pelanggan. Sedangkan penelitian yang dilakukan oleh Tangkilisan (2013) juga menunjukkan bahwa Understanding Customer Expectation berpegaruh positif dan signifikan terhadap loyalitas nasabah sehingga didapat hipotesis pertama dalam penelitian ini adalah:

$\mathrm{H}_{1}$ : Understanding Customer Expectation berpengaruh secara signifikan terhadap loyalitas pelanggan

Building Service Partnership merupakan hubungan kerjasama antara perusahaan dengan pelanggan yang dapat memberikan umpan balik berkelanjutan bagi perusahaan. Kerjasama ini berfokus pada hubungan jangka panjang antara perusahaan dengan pelanggan. Semakin dekatnya hubungan perusahaan dengan konsumen maka akan semakin loyal konsumen terhadap perusahaan tersebut. Penelitian yang dilakukan oleh Tangkilisan (2013), variabel Building Service Partnership berpengaruh positif dan signifikan terhadap loyalitas pelanggan. Demikian juga dengan penelitian yang dilakukan oleh Rahmawati (2013) yang menunjukkan bahwa 
Building Service Partnership berpengaruh positif dan signifikan terhadap loyalitas pelanggan. Dengan demikian dibuat hipotesis kedua dalam penelitian ini sebagai berikut:

$\mathrm{H}_{2}$ : Building Service Partnership berpengaruh signifikan terhadap loyalitas pelanggan.

Total Quality Management merupakan salah satu cara yang dapat dilakukan untuk meningkatkan mutu produk dan menghasilkan produk yang berkualitas. Semakin baik mutu produk yang dihasilkan maka loyalitas pelanggan juga akan meningkat. Penelitian yang dilakukan oleh Tangkilisan (2013) menyatakan bahwa Total Quality Management berpengaruh positif dan signifikan terhadap loyalitas pelanggan. Berdasarkan hasil penelitian Rahmawati (2013) juga menunjukkan bahwa Total Quality Management berpengaruh positif dan signifikan terhadap loyalitas pelanggan. Sehingga hipotesis ketiga yang dibuat dalam penelitian ini adalah:

$\mathrm{H}_{3}$ : Total Quality Management berpengaruh signifikan terhadap loyalitas pelanggan.

Pengaruh Empowering Employees terhadap Loyalitas Pelanggan Empowering Employees merupakan suatu kegiatan yang dilakukan perusahaan dalam membina karyawan sebaik - baiknya agar dapat mengatasi masalah yang dikeluhkan oleh konsumen. Menurut penelitian Anwar (2016) variabel Empowering Employees berpengaruh secara signifikan terhadap loyalitas pelanggan. Demikian juga penelitian yang dilakukan oleh Tangkilisan (2013) yang menyatakan bahwa variabel Empowering Employees berpengaruh positif dan signifikan terhadap loyalitas pelanggan. Hipotesis keempat yang dibuat dalam penelitian ini adalah:

$\mathrm{H}_{4}$ : Empowering Employees berpengaruh signifikan terhadap loyalitas pelanggan.

\section{METODE PENELITIAN}

Penelitian ini bertempat di PT. Pangkalan Baru Indah, Jalan Angkasa Nomor 11D Pekanbaru, Provinsi Riau. Sedangkan waktu yang digunakan dalam penelitian ini dimulai dari bulan Juli 2017 sampai dengan Januari 2018. Dalam penelitian ini yang menjadi populasi adalah seluruh konsumen yang membeli produk - produk yang dihasilkan PT. Pangkalan Baru Indah. Jumlah populasi dalam penelitian ini adalah 89 pelanggan. Sampel dalam penelitian diambil berdasarkan rumus Slovin sehingga didapat 47 sampel, Akan tetapi untuk menghindari adanya angket yang hilang ataupun tidak dapat digunakan dalam penelitian maka angket yang dibagikan berjumlah 65 angket.

\section{Definisi Operasional Variabel Penelitian}

Tabel 1. Definisi Operasional Variabel Penelitian

\begin{tabular}{|c|c|}
\hline $\begin{array}{c}\text { Variabel } \\
\text { Penelitian }\end{array}$ & Indikator \\
\hline $\begin{array}{l}\text { Understanding } \\
\text { Customer } \\
\text { Expectation }\end{array}$ & $\begin{array}{l}\text { 1. Harga sesuai kemampuan } \\
\text { 2. Pelayanan yang } \\
\text { memuaskan } \\
\text { 3. Produk dan fasilitas } \\
\text { sesuai harapan } \\
\text { (Wibowo S, 2006) }\end{array}$ \\
\hline $\begin{array}{l}\text { Building } \\
\text { Service } \\
\text { Partnership }\end{array}$ & $\begin{array}{l}\text { 1. Berdasarkan kejujuran } \\
\text { dan keterbukaan } \\
\text { 2. Kolaboratif antar pihak } \\
\text { 3. Komunikasi yang baik } \\
\text { (Evan dan Laskin, 1994) }\end{array}$ \\
\hline $\begin{array}{l}\text { Total Quality } \\
\text { Management }\end{array}$ & $\begin{array}{l}\text { 1 Produk sesuai standar } \\
\text { 2. Produk yang berkualitas } \\
\text { 3. Perbaikan kualitas secara } \\
\text { berkesinambungan } \\
\text { (Wibowo S, 2006) }\end{array}$ \\
\hline Empowering & 1. Tanggung jawab \\
\hline
\end{tabular}




\begin{tabular}{|c|c|}
\hline Employees & $\begin{array}{l}\text { karyawan } \\
\text { 2. Kemampuan karyawan } \\
\text { dalam menanggapi dan } \\
\text { menyelesaikan masalah } \\
\text { 3. Kemampuan karyawan } \\
\text { mengambil keputusan } \\
\text { (Evan dan Laskin, 1994) }\end{array}$ \\
\hline Loyalitas & 1. Repeat Purchase \\
\hline Pelanggan & $\begin{array}{l}\text { 2. Retention } \\
\text { 3. Referrals } \\
\text { (Kotler dan Keller, 2009) }\end{array}$ \\
\hline
\end{tabular}

Sumber: Data Olahan

Jenis data yang digunakan dalam penelitian ini meliputi data kuantitatif dan data kualitatif dimana proses pengumpulan data dilakukan melalui studi lapangan dan studi pustaka guna memperoleh data dan landasan teori yang berkaitan dengan topik penelitian Teknik pengolahan data dalam penelitian ini menggunakan program pengolahan data SPSS 19 dimana tahapan awal proses pengolahan data yaitu dengan melakukan uji validitas dan uji reliabilitas untuk menguji kelayakan kuesioner selanjutnya dilakukan uji asumsi klasik (uji multikolinearitas, uji autokorelasi, uji heteroskedastisitas, dan uji normalitas) untuk menguji apakah persamaan regresi dapat digunakan dalam penelitian. Kemudian dilakukan pengujian hipotesis baik parsial maupun simultan untuk menguji pengaruh variabel independen terhadap variabel depeden.

\section{HASIL DAN PEMBAHASAN}

PT. Pangkalan Baru Indah merupakan perusahaan yang bergerak di bidang industri pengolahan minyak sawit atau pabrik kelapa sawit (PKS) di Provinsi Riau yang berlamatkan Jalan Angkasa No 11D. Pembangunan pabrik PT. Pangkalan Baru Indah dimulai sejak tahun 2008 akan tetapi pembangunan sempat terhambat karena adanya kesalahan dalam pemasangan alat alat pengolahan sehingga PKS PT. Pangakalan Baru Indah baru diresmikan pada tahun 2011. Pada awalnya PKS ini hanya menerima sawit dari PT. Wasundari Indah dikarenakan produksi minyak yang belum maksimal dan juga peralatan yang belum memadai. Tetapi sekarang PKS ini telah semakin berkembang dan produksi minyaknya pun telah semakin bertambah. PT. Pangkalan Baru Indah merupakan salah satu badan usaha yang ada di Provinsi Riau yang bergerak dibidang industri pengolahan minyak sawit dan menjual beberapa produk olahan dari kelapa sawit seperti Crude Palm Oil, Palm Kernel, cangkang, dan produk olahan lainnya.

\section{Karakteristik Responden}

Responden dalam penelitian ini sebanyak 60 orang responden yang meliputi 43 laki-laki dan 17 perempuan dengan total 60 responden. Sehingga proporsi terbanyak responden berdasarkan jenis kelamin adalah laki - laki. Kategori umur responden yang melakukan pembelian pada PT. Pangakalan Baru Indah berada dalam kategori umur 20-25 tahun dengan total 5 responden, 25-30 tahun dengan total 14 responden, 30-35 tahun dengan total 13 responden, 3540 tahun dengan total 15 responden dan $\geq 40$ tahun dengan total 13 responden.

Dari segi pendidikan, jumlah responden mayoritas berpendidikan terakhir SMA yaitu sebanyak 31 responden, sedangkan sisanya sebanyak 12 responden berpendidikan terakhir diploma dan sebanyak 17 responden 
berpendidikan terakhir sarjana. Jika dilihat dari segi pekerjaan, pelanggan PT. Pangkalan Baru Indah mayoritas berasal dari kalangan wiraswasta dengan jumlah 30 responden, diikuti dengan kalangan karyawan swasta sebanyak 20 responden, lainnya sebanyak 8 responden dan dari kalangan PNS sebanyak 2 responden.

Tabel 2. Analisis Tanggapan Responden

\begin{tabular}{lcc}
\hline \multicolumn{1}{c}{ Variabel Penelitian } & Rata - Rata & Ket \\
\hline $\begin{array}{l}\text { Understanding } \\
\begin{array}{l}\text { Customer Expectation } \\
\text { (X1) }\end{array}\end{array}$ & 3,714 & Baik \\
\hline $\begin{array}{l}\text { Building Service } \\
\text { Partnership (X2) }\end{array}$ & 3,711 & Baik \\
\hline $\begin{array}{l}\text { Total Quality } \\
\text { Management (X3) }\end{array}$ & 3,650 & Baik \\
\hline $\begin{array}{l}\text { Empowering } \\
\text { Employees }(\mathrm{X} 4)\end{array}$ & 3,642 & Baik \\
\hline $\begin{array}{l}\text { Loyalitas Pelanggan } \\
\text { (Y) }\end{array}$ & 3,647 & Tinggi \\
\hline
\end{tabular}

\section{Sumber: Data Olahan}

\section{Uji Validitas dan Reliabilitas}

Uji validitas digunakan untuk mengukur sah atau tidaknya suatu kuesioner, suatu kuesioner dikatakan valid jika pernyataan pada kuesioner mampu untuk mengungkapkan sesuatu yang akan diukur oleh kuesioner tersebut. Uji validitas dihitung dengan membandingkan nilai $r$ hitung dengan nilai $r$ tabel, jika $r$ hitung lebih besar dari $r$ tabel (pada taraf signifikansi 5\%) maka pernyataan tersebut dinyatakan valid. Hasil uji validitas terhadap variabel independen dan variabel dependen menunjukkan nilai $r$ hitung lebih besar dari $r$ tabel. Hal ini memperlihatkan bahwa semua indikator dalam penelitian menghasilkan nilai yang valid.

Uji Reliabilitas menggunakan koefisien Cronbach's Alpha sama atau lebih dari 0,60. Hasil uji reliabilitas terhadap variabel independen dan variabel dependen dalam penelitian ini mempunyai
Cronbach's Alpha yang lebih besar daripada 0,60 . Hal ini menunjukkan bahwa semua variabel yang digunakan dalam penelitian mempunyai nilai yang reliabel.

Berdasarkan hasil pengujian validitas dan reliabilitas maka dapat ditarik kesimpulan bahwa kuesioner yang digunakan dalam penelitian ini merupakan kuesioner yang handal.

\section{Uji Asumsi Klasik}

\section{Uji Normalitas}

Pengujian normalitas dilakukan dengan grafik normal probability plot dan uji Kolmogorov Sminorv. Grafik normal probability plot pada penelitian ini tampak pada Gambar 3 berikut:

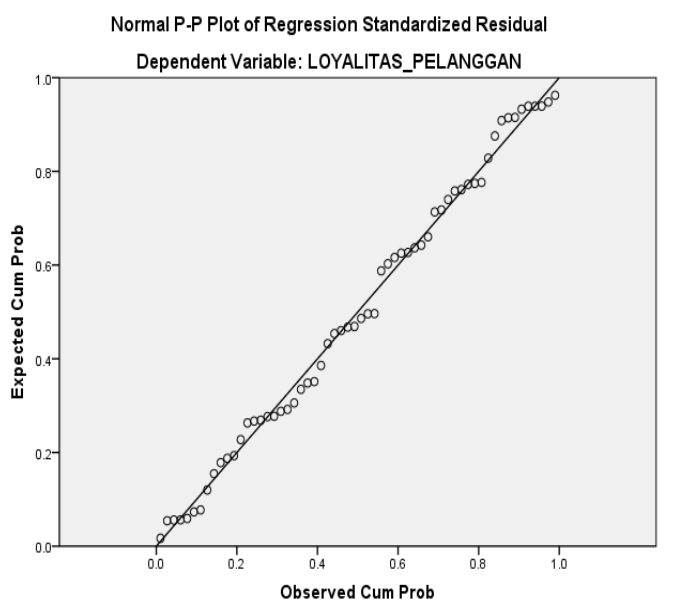

Sumber: Data Olahan

Gambar 3. Uji Normalitas P-P Plot

Uji normalitas dengan normal probability plot mensyaratkan bahwa penyebaran data harus berada disekitar wilayah garis diagonal dan mengikuti arah garis diagonal. Berdasarkan Gambar 3 di atas dapat disimpulkan bahwa data dalam penelitian ini memiliki distribusi yang normal karena titik - titik mendekati garis diagonal dan menunjukkan bahwa model regresi layak dipakai karena memenuhi syarat asumsi normalitas.

Berdasarkan hasil uji Kolmogorov Sminorv Test, diperoleh 
tingkat signifikansi sebesar 0,197. Nilai signifikansi $0,197>0,05$ dengan demikian dapat disimpulkan bahwa semua data dari variabel yang diteliti memiliki pola distribusi normal. Hal ini berarti model regresi layak dipakai karena memenuhi syarat asumsi normalitas.

\section{Uji Heteroskedastisitas}

Dalam penelitian ini uji heteroskodesitas dilakukan dengan analisa grafik scatterplot antara nilai prediksi variabel terikat (ZPRED) dengan residualnya (SRESID) dan juga menggunakan metode Glejser.

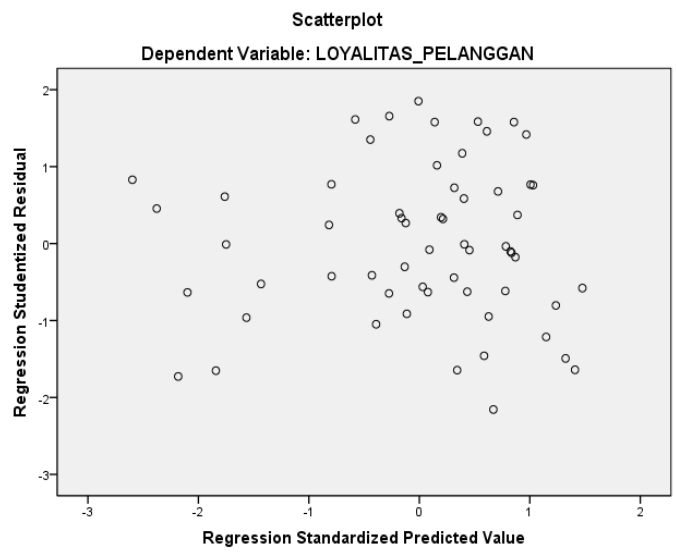

Sumber: Data Olahan

\section{Gambar 4. Uji Heteroskedastisitas}

Berdasarkan Gambar 4

diatas, terlihat bahwa titik - titik yang ada didalam grafik tersebar atau titik - titik tidak membetuk pola tertentu maka tidak terjadi heteroskedastisitas. Sehingga dapat disimpulkan bahwa data dalam penelitian ini tidak terjadi heteroskedastisitas. Dengan demikian, disimpulkan bahwa model yang digunakan dalam penelitian ini memenuhi asumsi klasik.

Berdasarkan hasil uji Glejser, diperoleh tingkat signifikansi untuk semua variabel dalam penelitian lebih besar dari 0,05 sehingga dapat disimpulkan bahwa semua data dari variabel yang diteliti tidak terjadi heteroskedastisitas.

\section{Uji Multikolinearitas}

Uji multikolinieritas bertujuan untuk menguji ada tidaknya korelasi antara variabel independent (bebas) dan variabel dependent (terikat) dalam suatu model regresi. Hasil pengujian menunjukkan bahwa semua variabel independen memiliki nilai tolerance yang lebih besar dari 0,10 dan nilai Variance Inflation Factor (VIF) yang lebih kecil dari 10. Jadi, dapat disimpulkan bahwa tidak ada multikolinearitas antar variabel independen dalam model regresi.

\section{Uji Autokorelasi}

Uji Autokorelasi merupakan pengujian yang dilakukan untuk menguji ada tidaknya pengaruh antara variabel penganggu dalam masing - masing variabel bebas. Pengujian dilakukan dengan melihat nilai Durbin-Watson (DW). Dari hasil pengujian diperoleh nilai DW sebesar 1,971. Sehingga nilai DW berada diantara dU $(1,727)<\mathrm{DW}$ $(1,971)<4-\mathrm{dU}(4-1,727=2,273)$. Maka dapat disimpulkan bahwa dalam penelitian ini tidak terdapat autokorelasi. Artinya bahwa variabel bebas dalam penelitian ini tidak terganggu atau terpengaruhi oleh variabel pengganggu.

\section{Analisis Regresi Berganda}

Dari hasil uji analisis regresi linier berganda penelitian ini dapat dibuat persamaan sebagai berikut:

$$
\begin{gathered}
Y=-1,591+0,374 X 1+0,167 X 2 \\
+0,451 X 3+0,071 X 4
\end{gathered}
$$

Koefisien yang terdapat pada persamaan diatas dapat dijelaskan sebagai berikut konstanta sebesar 1,591 menunjukkan bahwa seluruh variabel bebas sama dengan nol 
maka rata - rata loyalitas pelanggan adalah sebesar $\quad-1,591$. Understanding Customer Expectation memiliki koefisien positif sebesar 0,374 yang artinya untuk setiap pertambahan Understanding Customer Expectation satu satuan akan menyebabkan meningkatnya loyalitas pelanggan sebesar 0,374. Building service partnership memiliki koefisien positif sebesar 0,167 yang artinya untuk setiap pertambahan building service partnership satu satuan akan menyebabkan meningkatnya loyalitas pelanggan sebesar 0,167. Total quality management memiliki koefisien positif sebesar 0,451 yang artinya untuk setiap pertambahan total quality management satu satuan akan menyebabkan meningkatnya loyalitas pelanggan sebesar 0,451. Empowering employees memiliki koefisien positif sebesar 0,071 yang artinya untuk setiap pertambahan empowering employees satu satuan akan menyebabkan meningkatnya loyalitas pelanggan sebesar 0,071 .

\section{Uji Model (Uji F)}

Untuk mengetahui signifikan pengaruh variabel-variabel bebas secara bersama-sama atas suatu variabel terikat digunakan uji $\mathrm{F}$. Dasar pengambilan keputusan adalah nilai signifikansi harus lebih kecil dari 0,05 dan nilai f-hitung harus lebih besar dari nilai f-tabel $(2,54)$.

Tabel 3. Hasil Uji Model (Uji F)

\begin{tabular}{cccc}
\hline F-hitung & F-tabel & Sig. & $\boldsymbol{\alpha}$ \\
\hline 36,577 & 2,54 & 0,000 & 0,050
\end{tabular}

\section{Sumber: Data Olahan}

Berdasarkan hasil pengujian diperoleh nilai signifikansi adalah sebesar 0,00. Dasar pengambilan keputusan adalah tingkat signifikansinya $5 \%$ atau 0,05 . Karena nilai signifikansi lebih kecil dari 0,05 maka menunjukkan bahwa secara simultan understanding customer expectation, building service partnership, total quality management dan empowering employees berpengaruh secara signifikan terhadap loyalitas pelanggan.

Dasar pengambilan keputusan yang lain adalah nilai fhitung harus lebih besar dari nilai ftabel untuk mengetahui adanya pengaruh dari variabel bebas terhadap variabel terikat. Dari tabel diatas dapat dilihat bahwa nilai fhitung adalah sebesar 36,577 yang lebih besar daripada nilai f-tabel 2,54 maka dapat disimpulkan bahwa secara simultan understanding customer expectation, building service partnership, total quality management dan empowering employees berpengaruh secara signifikan terhadap loyalitas pelanggan.

\section{Uji Koefisien Determinasi $\left(\mathbf{R}^{\mathbf{2}}\right)$}

Uji koefisien determinasi digunakan untuk mengukur seberapa jauh kemampuan model dalam menerangkan variabel dependen. Nilai yang digunakan dalam koefisien determinasi adalah dengan menggunakan nilai Adjusted $R$ Square.

Tabel 4. Hasil Uji Koefisien Determinasi $\left(\mathbf{R}^{2}\right)$

\begin{tabular}{cccc}
\hline $\mathbf{R}$ & R Square & $\begin{array}{c}\text { Adjusted } \boldsymbol{R} \\
\text { Square }\end{array}$ & $\begin{array}{c}\text { Std. Error } \\
\text { of Estimate }\end{array}$ \\
\hline 0,853 & 0,727 & 0,707 & 1,76650 \\
\hline
\end{tabular}

Sumber: Data Olahan 
Nilai Adjusted $R$ Square dalam penelitian ini adalah sebesar 0,707 atau $70,7 \%$, hal ini berarti sebesar $70,7 \%$ loyalitas pelanggan dipengaruhi oleh variasi dari variabel understanding customer expectation, building service partnership, total quality management dan empowering employees. Sedangkan sisanya sebesar 29,3\% dipengaruhi oleh variabel lainnya yang tidak dimasukkan kedalam model regresi dalam penelitian ini.

\section{Uji Parsial (Uji t)}

Tabel 5. Hasil Uji Parsial (Uji t)

\begin{tabular}{lllll}
\hline \multicolumn{1}{|l}{$\begin{array}{l}\text { Variabel t-hitung t-tabel } \\
\text { Penelitian }\end{array}$} & Sig. & $\boldsymbol{\alpha}$ \\
\hline $\begin{array}{l}\text { Understanding } \\
\begin{array}{l}\text { Customer } \\
\text { Expectation }\end{array}\end{array}$ & 4,222 & 2,004 & 0,000 & 0,050 \\
$(\mathrm{X} 1)$ & & & & \\
\hline Building & & & & \\
\hline
\end{tabular}

\begin{tabular}{lllll}
\hline Building & & & & \\
Service & 2,226 & 2,004 & 0,030 & 0,050 \\
Partnership & & & & \\
(X2) & & & & \\
\hline
\end{tabular}

(X2)

Total Quality

Management $\quad 4,430 \quad 2,004 \quad 0,000 \quad 0,050$

(X3)

Empowering

Employees $\quad 0,886 \quad 2,004 \quad 0,379 \quad 0,050$

(X4)

Sumber: Data Olahan

$$
\text { Variabel understanding }
$$

customer expectation memiliki nilai t-hitung sebesar 4,222 dan nilai signifikansi sebesar 0,000 sehingga thitung > t-tabel $(2,004)$ dan nilai signifikansi $<\alpha(0,050)$, maka dapat disimpulkan bahwa $\mathrm{H}_{1}$ diterima. Yang artinya variabel understanding customer expectation berpengaruh signifikan terhadap loyalitas pelanggan PT. Pangkalan Baru Indah. Variabel building service partnership memiliki nilai t-hitung sebesar 2,226 dan nilai signifikansi sebesar 0,030 yang mengindikasikan bahwa nilai t-hitung > t-tabel $(2,004)$ dan nilai signifikansi $<\alpha(0,050)$. Sehingga dapat disimpulkan bahwa $\mathrm{H}_{2}$ diterima yang berarti building service partnership berpengaruh signifikan terhadap loyalitas pelanggan pada PT. Pangkalan Baru Indah. Variabel total quality management memiliki nilai t-hitung sebesar 4,430 dan nilai signifikansi sebesar 0,000 yang mengindikasikan bahwa nilai t-hitung $>$ t-tabel $(2,004)$ dan nilai signifikansi $<\alpha(0,050)$. Sehingga dapat disimpulkan bahwa $\mathrm{H}_{3}$ diterima yang berarti total quality management berpengaruh signifikan terhadap loyalitas pelanggan pada PT. Pangkalan Baru Indah. Variabel empowering employees memiliki nilai t-hitung sebesar 0,886 dan nilai signifikansi sebesar 0,379 yang mengindikasikan bahwa nilai $t$ hitung < t-tabel $(2,004)$ dan nilai signifikansi $>\alpha(0,050)$. Sehingga dapat disimpulkan bahwa $\mathrm{H}_{4}$ ditolak yang berarti empowering employees tidak berpengaruh dan tidak signifikan terhadap loyalitas pelanggan pada PT. Pangkalan Baru Indah.

Variabel understanding customer expectation memiliki nilai t-hitung yang lebih besar dari t-tabel dan nilai signifikansi yang lebih kecil dari $\alpha$, yang artinya variabel understanding customer expectation berpengaruh signifikan terhadap loyalitas pelanggan PT. Pangkalan Baru Indah. Tanggapan responden tertinggi terletak pada indikator kedua sedangkan tanggapan responden terendah terletak pada indikator ketiga. Hasil penelitian ini mendukung penelitian yang dilakukan oleh Anwar (2016) dan Tangkilisan (2013) yang juga 
menunjukkan bahwa understanding customer expectation berpengaruh signifikan terhadap loyalitas pelanggan.

Variabel building service partnership memiliki nilai t-hitung yang lebih besar dari t-tabel dan nilai signifikansi yang lebih kecil dari $\alpha$ yang berarti building service partnership berpengaruh signifikan terhadap loyalitas pelanggan pada PT. Pangkalan Baru Indah. Tanggapan responden tertinggi terletak pada indikator kedua sedangkan tanggapan responden terendah terletak pada indikator kelima. Hasil penelitian ini mendukung penelitian yang dilakukan oleh Tangkilisan (2013) dan Rahmawati (2013) yang menunjukkan bahwa building service partnership berpengaruh signifikan terhadap loyalitas pelanggan. Variabel total quality management memiliki nilai t-hitung yang lebih besar dari t-tabel dan nilai signifikansi yang lebih kecil dari $\alpha$ yang berarti total quality management berpengaruh signifikan terhadap loyalitas pelanggan pada PT. Pangkalan Baru Indah. Tanggapan responden tertinggi terletak pada indikator pertama sedangkan tanggapan responden terendah terletak pada indikator keenam. Hasil penelitian ini mendukung penelitian yang dilakukan oleh Tangkilisan (2013) dan Rahmawati (2013) yang menunjukkan bahwa total quality management berpengaruh signifikan terhadap loyalitas pelanggan. Variabel

empowering employees memiliki nilai t-hitung yang lebih kecil dari t-tabel dan nilai signifikansi yang lebih besar dari $\alpha$ yang berarti empowering employees tidak berpengaruh dan tidak signifikan terhadap loyalitas pelanggan pada PT. Pangkalan Baru Indah. Tanggapan responden tertinggi terletak pada indikator keempat sedangkan tanggapan responden terendah terletak pada indikator kedua. Hasil penelitian ini bertolak belakang dengan penelitian yang dilakukan oleh Kumbokarno Borneo (2011) dan Anwar (2016) yang menyatakan bahwa empowering employees berpengaruh signifikan terhadap loyalitas pelanggan.

\section{PENUTUP}

\section{Kesimpulan}

Berdasarkan hasil penelitian tentang pengaruh Relationship Marketing terhadap loyalitas pelanggan pada PT. Pangkalan Baru Indah, maka dapat disimpulkan variabel understanding customer expectation berpengaruh positif dan signifikan terhadap loyalitas pelanggan pada PT. Pangkalan Baru Indah., variabel building service partnership berpengaruh positif dan signifikan terhadap loyalitas pelanggan pada PT. Pangkalan Baru Indah. Variabel total quality management berpengaruh positif dan signifikan terhadap loyalitas pelanggan pada PT. Pangkalan Baru Indah. Variabel empowering employees berpengaruh positif namun tidak berpengaruh signifikan terhadap loyalitas pelanggan pada PT. Pangkalan Baru Indah.

Saran

Berdasarkan kesimpulan diatas, maka disarankan bagi 
perusahaan diharapkan untuk dapat meningkatkan interaksi dengan pelanggan untuk lebih memahami harapan pelanggan terhadap produk dari PT. Pangkalan Baru Indah, meningkatkan hubungan kerjasama jangka panjang dengan pelanggan yaitu dengan tetap konsisten menjaga komitmen bersama dan menjaga kepercayaan pelanggan terhadap PT. Pangkalan Baru Indah, meningkatkan penerapan Total Quality Management melalui perbaikan secara berkelanjutan antara lain dengan peningkatan kualitas dan mutu produk, dan melakukan perbaikan fasilitas serta perusahaan perlu melakukan upaya pemberdayaan karyawan (empowering employees) oleh perusahaan kepada karyawannya serta berusaha memenuhi kebutuhan pelanggan dan menyelesaikan permasalahan pelanggan. Dan juga bagi akademisi jika akan menggunakan skripsi ini sebagai referensi untuk penelitian dalam bidang yang sama, maka kiranya perlu dikaji kembali.

\section{DAFTAR PUSTAKA}

Anwar. (2016). Kajian Implementasi Relationship Marketing Terhadap Customer Loyalty (Loyalitas Mahasiswa) (Kasus pada Fakultas Ekonomi Universitas Muhammadiyah Jember). Jurnal Manajemen Dan Bisnis Indonesia, 2(2):4657.

Borneo, Kumbokarno. (2011). Pengaruh Implementasi Relationship Marketing Terhadap Loyalitas Konsumen Pada Produk Oli Pelumas PT.
Pertamina (Persero) Enduro 4T. Jurnal Ekonomi 1(1).

Chan, Syafruddin. (2003). Relationship Marketing: Inovasi Pemasaran Yang Membuat Pelanggan Bertekuk Lutut. Gramedia. Jakarta.

Ghozali, Imam. (2011). Aplikasi Analisis Multivariate Dengan Program SPSS 19. Cetakan kelima. Badan Penerbit Universitas Diponegoro. Semarang.

Hindarto, Peter D. (2013). Hubungan Relationship Marketing Dengan Loyalitas Pelanggan Ritel. Jurnal JIBEKA 7(3):41 46.

Junistyaningrum Nurulita dan Sugiarto Y. (2016). Pengaruh Implementasi Relationship Marketing Terhadap Customer Loyalty Dengan Cutomer Satisfaction Sebagai Variabel Intervening. Diponegoro Journal of Accounting 5(1):1 14.

Kotler, Philip dan Keller, Kevin L. (2009). Manajemen Pemasaran Edisi 12 Jilid 1. Indeks. Jakarta.

Kotler, Philip \& Gary Armstrong. (2006). Principles of Marketing Eleventh Edition. Pearson Prentice Hall. New Jersey.

Prihantoro, Rudy. (2012). Konsep Pengendalian Mutu. PT. Remaja Rosdakarya. Bandung.

Rahmawati, Novia Y. (2016). Pengaruh Relationship Marketing Terhadap Loyalitas Nasabah Pada PT. Bank Negara Indonesia (Persero) Tbk Cabang Malang. Jurnal Fakultas Ekonomi dan Bisnis, Universitas Brawijaya. Malang. 
Saputri, Juwita, Fransisca Yaningwati dan Dahlan Fanani. 2013. Pengaruh Implementasi Relationship Marketing Terhadap Loyalitas Pelanggan (Survei pada Nasabah PT. XXX Cabang Malang). Jurnal Fakultas Administrasi, Universitas Brawijaya. Malang. Sugiyono, (2014). Metode Penelitian Kombinasi. Cetakan Kedua. Penerbit Alfabeta. Bandung.

Tangkilisan, Fendy G. (2013). Relationship Marketing Pengaruhnya Terhadap Customer Loyalty Pada PT. Bank Perkreditan Rakyat Prisma Dana Manado. Jurnal EMBA 1(4): 224 - 233.

Tunggal A. W. (2008). Definisi Loyalitas Pelanggan (customer loyalty definition). http://ilmumanajemenpemasara n.wordpress.com/2009/11/10/d efinisi-loyalitas-pelanggan/. Diakses tanggal 20 September 2017.

Wibowo, S. (2006). Implementasi Releationship Marketing Pada Industri Hospitality. Utilitas, Volume 14, Nomor 2, Juni 2006. 